\title{
STRATEGI BERTAHAN HIDUP KELUARGA NELAYAN DANAU TOBA DI DESA LUMBAN BINANGA KECAMATAN LAGUBOTI KABUPATEN TOBA SAMOSIR
}

\author{
Taruli Sianipar', Kamarlin Pinem² \\ 'Alumnus S1 Jurusan Pendidikan Geografi Fakultas Ilmu Sosial Universitas Negeri Medan \\ 2Jurusan Pendidikan Geografi Fakultas Ilmu Sosial Universitas Negeri Medan \\ Jl. Willem Iskandar Psr V Medan Estate Medan, 20211 Indonesia \\ Email: kamarlinpinem@unimed.ac.id
}

\begin{abstract}
Abstrak
Tujuan dari penelitian ini adalah untuk mengetahui Strategi Bertahan Hidup Keluarga Nelayan Danau Toba di Desa Lumban Binanga Kecamatan Laguboti Kabupaten Toba Samosir. Populasi dalam penelitian ini adalah seluruh masyarakat yang bermata pencaharian utama sebagai nelayan yang ada di Desa Lumban Binanga yang berjumlah 30 Kepala Keluarga (KK). Populasi dalam penelitian ini sekaligus dijadikan sebagai sampel dengan teknik pengambilan sampelnya adalah total sampling. Teknik analisis data yang digunakan dalam penelitian ini adalah dengan menggunakan analisis deskriptif kualitatif. Dalam teknik analisis data ini dibantu dengan tabel frekuensi dan perhitungan persentase sehingga dapat ditarik kesimpulan Strategi Bertahan Hidup Keluarga Nelayan Danau Toba di Desa Lumban Binanga Kecamatan Laguboti Kabupaten Toba Samosir. Hasil penelitian menunjukkan bahwa pekerjaan sebagai nelayan Danau Toba tidak mampu mensejahterakan seluruh anggota keluarga, karena dengan penghasilan Rp. 1.288.000-Rp. 1.930.000 perbulannya tidak cukup untuk memenuhi seluruh kebutuhan rumah tangga mereka. Oleh karena itu keluarga nelayan Danau Toba di Desa Lumban Binanga melakukan berbagai cara sebagai bentuk strategi bertahan hidup. Untuk strategi ekonomi Keluarga Nelayan memilih diversifikasi kerja atau kepala keluarga memiliki pekerjaan sampingan sebanyak 28 responden atau 93,33\%. Terdapat 26 responden atau $86,66 \%$ yang mengikutsertakan istri untuk bekerja dengan jenis pekerjaan dominan yaitu sebanyak 17 responden atau 65,38\% yang memilih untuk bekerja sebagai petani. Sebanyak 30 responden atau 100\% memilih untuk melakukan penghematan atau menekan pengeluaran Untuk strategi sosial, sebanyak 30 responden atau 100\% memilih untuk memanfaatkan jaringan sosial sebagai strategi bertahan hidup yang selanjutnya, dimana sebanyak 16 responden atau 53,33\% memilih untuk meminjam uang kepada tauke padi. Untuk strategi campuran, terdapat 26 responden atau 86,66\% yang memilih untuk melakukannya, yaitu dengan cara melaksanakan keempat strategi tersebut secara bersamaan.
\end{abstract}

Kata kunci: Strategi, Masyarakat, Nelayan, Danau Toba

\section{PENDAHULUAN}

Pembangunan Nasional adalah upaya untuk meningkatkan seluruh aspek kehidupan masyarakat, bangsa, dan negara yang sekaligus merupakan proses pembangunan keseluruhan untuk mewujudkan tujuan nasional yaitu meningkatkan kesejahteraan kehidupan masyarakat dan negara yang maju dan demokrasi berdasarkan Pancasila.Untuk mencapai kehidupan masyarakat yang sejahtera, mengembangkan dan mengelola sumberdaya alam yang tersedia merupakan cara yang tepat. Salah satu sumberdaya alam yang dapat membantu meningkatkan kesejahteraan masyarakat adalah sumberdaya perairan darat.

Perairan darat adalah semua bentuk air yang terdapat di daratan, dengan danau sebagai salah satu contoh. Danau merupakan sumberdaya alam yang dapat dimanfaatkan secara bersama oleh masyarakat sekitar dengan menjadikan nelayan sebagai pekerjaan utama. Salah satu danau yang memiliki sumberdaya perikanan adalah Danau Toba. Danau 
Toba merupakan danau kaldera terbesar di dunia yang terletak di Provinsi Sumatera Utara, berjarak $176 \mathrm{~km}$ ke arah Barat Kota Medan sebagai ibu kota provinsi.Danau Toba mempunyai sumberdaya yang berlimpah seperti ikan dengan berbagai macam jenisnya. Kekayan Danau Toba yang berlimpah itu seharusnya dapat menjadi jaminan masa depan masyarakat sekitar terutama yang bermata pencaharian sebagai nelayan. Namun pada kenyataannya, sangat menyedihkan saat kita melihat nasib nelayan yang ada saat ini. Kehidupan para nelayan sampai saat ini belum dapat dikatakan layak bahkan jauh dari kata sejahtera, kontras dengan perannya sebagai pahlawan protein bangsa.

Diantara kategori pekerjaan yang terkait dengan kemiskinan, nelayan sering disebut sebagai salah satu masyarakat miskin dari kelompok masyarakat lainnya. Menurut data Badan Pusat Statistik jumlah nelayan miskin di Indonesia pada tahun 2011 mencapai 7,87 juta orang atau 25,14 persen dari total penduduk miskin nasional yang mencapai 31,02 juta orang. Kesejahteraan dapat diukur berdasarkan aspek sosial dan aspek ekonominya. Masalah kesejahteraan selalu berhubungan dengan konsep kebutuhan, masyarakat nelayan/rumah tangga nelayan dapat dikatakan sejahtera apabila mereka mampu untuk memenuhi kebutuhan hidupnya.

Kabupaten Toba Samosir adalah salah satu kabupaten yang ada di Provinsi Sumatera Utara yang baru terbentuk pada tahun 1999, yang merupakan pemekaran dari Kabupaten Tapanuli Utara. Secara geografis Kabupaten Toba Samosir terletak di Dataran Tinggi Bukit Barisan dengan topografi dan kontur tanah datar, landai, bergelombang, miring dan terjal dengan ketinggian antara 300-2200 meter di atas permukaan laut.

Kecamatan Laguboti merupakan salah satu kecamatan yang berada di wilayah Kabupaten Toba Samosir. Kecamatan ini memiliki luas wilayah 73,90 $\mathrm{Km}^{2}$ (BPS). Ditinjau dari topologi daerah Kecamatan Laguboti merupakan area perladangan dan persawahan hal ini terlihat dari banyak tanaman-tanaman ladang dan tanaman padi yang menghiasi hampir sebagian besar luas wilayah. Kecamatan Laguboti yang berbatasan langsung dengan Danau Toba,mendorong sebagian masyarakat untuk bekerja sebagai nelayan, dengan demikian apabila dilihat dari sudut pandang geografi maka hal ini disebut sebagai prinsip interelasi yaitu adanya hubungan antara gejala fisik dan non fisik dan prinsip ini dapat mengungkapkan gejala geografi di suatu wilayah. Diantara 22 desa dan 1 kelurahan yang terdapat di Kecamatan Laguboti, salah satu desa yang sebagian penduduknya bekerja sebagai nelayan yakni Desa Lumban Binanga.

Desa Lumban Binanga merupakan sebuah desa yang berada di wilayah pesisir danau dengan luas lahan $105 \mathrm{Ha}$, dimana $33 \mathrm{Ha}$ diantaranya adalah untuk pemukiman dan sisanya berupa lahan pertanian. Desa Lumban Binanga memiliki jumlah penduduk sekitar 660 jiwa atau 90 Kepala Keluarga (KK), dimana 33\% diantaranya memiliki mata pencaharian utama sebagai nelayan, sedangkan yang lainnya bekerja sebagai petani, buruh tani, pedagang dan lain-lain.

Berdasarkan hasil survei awaldapat dilihat bagaimana kondisi kehidupanmasyarakat nelayan Danau Toba. Indikasi kemiskinan masyarakat nelayan Danau Toba dapat dilihat dari rendahnya pendapatan yang dipengaruhi oleh peralatan tangkap yang masih tergolong sederhana, yaitu dengan menggunakan sampan atau perahu kecil dengan kapasitas satu sampai dua orang, serta jaring sebagai alat penangkap ikan, dimana hal ini akan mempengaruhi jumlah tangkapan ikan yang terkadang tidak mampu memenuhi kebutuhan hidup keluarga. Rendahnya standar hidup masyarakat nelayan dapat dilihat darirumah penduduk yang sebagian besar terbuat dari papan dengan kondisi lingkungan pemukiman yang buruk menjadikan rumah yang dimiliki oleh masyarakat nelayan kurang layak 
huni.Pada tahun 2015, masyarakat Desa Lumban Binanga melalui Kepala Desa telah mengajukan permohonan kepada Pemerintah Kabupaten untuk memberikan bantuan kepada nelayan berupa perahu atau sampan yang lebih besar, alat tangkap ikan yang lebih modern, akan tetapi hingga saat ini permohonan bantuan tersebut belum juga terealisasikan, sehingga kemiskinan masyarakat nelayan Danau Toba masih terus berlanjut hingga saat ini.

Mencari nafkah bertujuan untuk memenuhi segala kebutuhan anggota keluarga, seperti kebutuhan pangan, kebutuhan akan kesehatan dan juga akses pendidikan bagi anak-anak mereka, akan tetapi jika dilihat dari pendapatan nelayan di Desa Lumban Binanga yang minim dan tidak menentu tentu hal tersebut sangat sulit terwujud. Hal ini tentunya berakibat buruk bagi nelayan di Desa Lumban Binanga karena ditengah pendapatan nelayan yang minim serta peluang kerja yang sulit, menuntut para nelayan berjuang keras untuk mencukupi kebutuhan hidup ditengah mahalnya biaya hidup, halini membuat masyarakat nelayan menempuh berbagai cara dan memilih berbagai strategi untuk tetap bertahan hidup dan mengatasi kemiskinan ditengah himpitan ekonomi yang serba kekurangan.Melihat gambaran kondisi masyarakat nelayan tersebut maka perlu dilakukan penelitian mengenai strategi bertahan hidup keluarga nelayan Danau Toba di lokasi tersebut.

Berdasarkan latar belakang masalah, maka yang menjadi identifikasi masalah dalam penelitian ini adalah: (1) Rendahnya pendapatan keluarga nelayan Danau Toba, (2) Rendahnya standar hidup keluarga Danau Toba, (3) Bantuan Pemkab yang belum terealisasikan, (4) Strategi yang dipilih keluarga nelayan untuk bertahan hidup.

Untuk menghindari pembahasan yang meluas dan tidak terarah maka perhatian utama dalam penelitian ini adalah Strategi Bertahan Hidup Keluarga Nelayan Danau Toba di Desa Lumban Binaga Kecamatan Laguboti Kabupaten Toba Samosir.
Berdasarkan perumusan masalah diatas, maka tujuan dari penelitian ini adalah untuk mengetahui Strategi Bertahan Hidup Keluarga Nelayan Danau Toba di Desa Lumban Binanga Kecamatan Laguboti Kabupaten Toba Samosir.

\section{METODE PENELITIAN}

Sesuai dengan judul penelitian maka lokasi penelitian ini dilakukan di Desa Lumban Binanga Kecamatan Laguboti Kabupaten Toba Samosir. Adapun yang menjadi alasan untuk memilih lokasi penelitian ini adalah karena: (1) masyarakat Nelayan Danau Toba yang ada di Desa Lumban Binanga ini masih ada yang belum sejahtera, (2) Sepanjang pengetahuan penulis belum pernah dilaksanakan penelitian yang serupa di daerah ini.

Populasi dalam penelitian ini adalah seluruh masyarakat yang bermata pencaharian utama sebagai nelayan yang ada di Desa Lumban Binanga yang berjumlah 30 Kepala Keluarga (KK). Populasi dalam penelitian ini sekaligus dijadikan sebagai sampel dengan teknik pengambilan sampelnya adalah total sampling.

Variabel penelitian merupakan objek suatu penelitian atau apa yang menjadi titik tolak dalam penelitian. Variabel yang digunakan dalam penelitian ini adalah Strategi bertahan hidup ditinjau dari 2 aspek yaitu aspek ekonomi dan aspek sosial.

Teknik pengumpulan data yang dilakukan dalam melihat penelitian ini adalah Teknik komunikasi langsung, dengan alat yang digunakan berupa lembar wawancara dengan menggunakan pertanyaan-pertanyaan secara lisan kepada responden sehingga dapat memberikan informasi yang tepat tentang objek yang diteliti terutama mengenai stratrgi bertahan hidup keluarga nelayan Danau Toba.

Teknik analisis data yang digunakan dalam penelitian ini adalah dengan menggunakan analisis deskriptif kualitatif. Dalam teknik analisis data ini dibantu dengan tabel frekuensi dan perhitungan 
persentase sehingga dapat ditarik kesimpulan Strategi Bertahan Hidup Keluarga Nelayan Danau Toba di Desa Lumban Binanga Kecamatan Laguboti Kabupaten Toba Samosir.

Adapun langkah-langkah dalam menganalisis deskriptif presentase adalah sebagai berikut: (Bungin, 2015)

a. Membuat tabel distribusi jawaban angket

b. Menghitung frekuensi responden untuk setiap kategori jawaban

c. Memasukkan hasil hitungan tersebut kedalam rumusan sebagai berikut:

$$
P=\frac{F}{N} x 100 \%
$$

Dimana :

$\mathrm{P}=$ Presentasi dari jawaban Responden

$\mathrm{F}=$ Frekuensi jawaban responden

$\mathrm{N}=$ Jumlah responden

$100 \%$ adalah bilangan tetap.

\section{HASIL DAN PEMBAHASAN}

Deskripsi Daerah Penelitian
Desa Lumban Binanga merupakan salah satu desa yang berada di Kecamatan Laguboti Kabupaten Toba Samosir. Berdasarkan letak astronomisnya, Desa Lumban Binanga terletak pada 2,37090 LU dan 99,11130 BT. Luas wilayah Desa Lumban Binanga adalah $105 \mathrm{Ha}$ yang terdiri dari 31,4 \% diantaranya adalah untuk permukiman dan 69,6 \% untuk lahan pertanian. Jarak tempuh dari desa ke ibukota kecamatan adalah $5 \mathrm{Km}$ dan dari desa ke ibukota kabupaten adalah $15 \mathrm{Km}$. Secara geografis wilayah Desa Lumban Binanga berbatasan langsung dengan:

$>$ Sebelah Utara berbatasan dengan Danau Toba

> Sebelah Selatan berbatasan dengan Desa Lumban Bagasan

$>$ Sebelah Timur berbatasan dengan Danau Toba dan Desa Pardinggaran

$>$ Sebelah Barat berbatasan dengan Danau Toba

Untuk melihat letak Desa Lumban Binanga baik secara astronomis dan geografis dapat dilihat pada gambar peta Desa Lumban Binanga berikut ini:
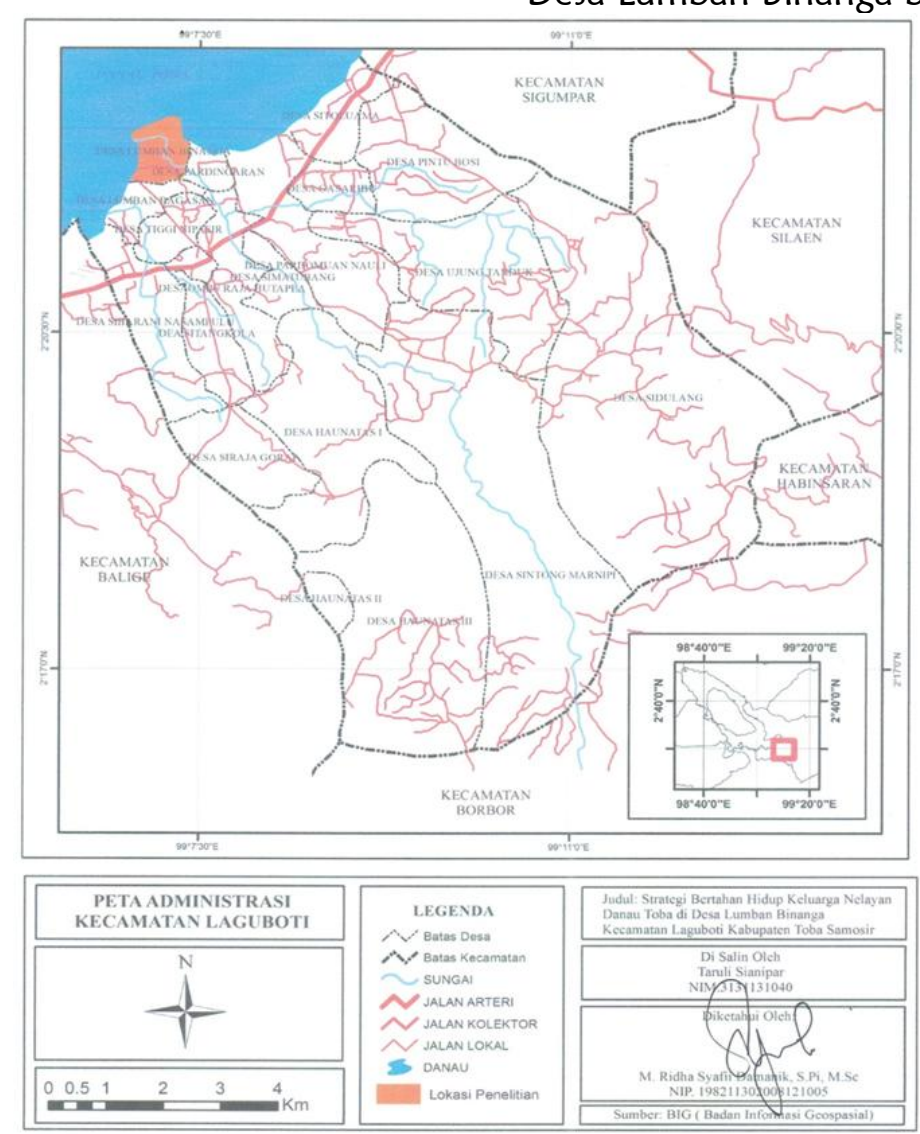

Gambar 1. Peta Administrasi Kecamatan Laguboti 
Topografi merupakan gambaran dari bentuk serta relief dari permukaan bumi suatu wilayah yang diukur dari permukaan laut. Berdasarkan data sekunder yang diperoleh penulis dari kantor Desa Lumban Binanga, Desa Lumban binanga berada pada ketinggian 910 meter diatas permukaan laut (mdpl), dan memiliki topografi yang relatif datar (BPS Kabupaten Toba Samosir, tahun 2016).

Iklim merupakan keadaan rata-rata cuaca pada tempat yang relatif luas dalam kurun waktu yang lama. Lumban Binanga terletak pada wilayah beriklim tropis basah dengan suhu berkisar antara $17^{\circ} \mathrm{C}-29^{\circ} \mathrm{C}$ dan rata-rata kelembaban udara 85,04\% (BPS Kabupaten Toba Samosir, tahun 2016).

Desa Lumban Binanga memiliko luas $105 \mathrm{Ha}$ yang digunakan sebagai lahan permukiman, lahan-lahan kering, persawahan, perkantoran dana lahan prasarana umum. Untuk lebih jelasnya, bentuk penggunaan lahan di Desa Lumban Binanga dan luas dari setiap masing-masing penggunaan lahan dapat dilihat pada tabel 1.

Tabel 1. Bentuk Penggunaan Lahan di Desa Lumban Binanga Tahun 2016

\begin{tabular}{|c|l|r|r|}
\hline No & \multicolumn{1}{|c|}{ Penggunaan Lahan } & Luas Lahan $(\mathrm{Ha})$ & Persentase (\%) \\
\hline 1 & Lahan Permukiman & 33 & 31,42 \\
2 & Lahan Kering & 20 & 19,04 \\
3 & Lahan Persawahan & 45 & 42,85 \\
4 & Perkantoran & 0,5 & 0,47 \\
5 & Lahan Prasarana Umum & 6,5 & 6,19 \\
\hline & Jumlah & 105 & 100 \\
\hline
\end{tabular}

Sumber: Kantor Kepala Desa Lumban Binanga, 2016

Sesuai dengan tabel 1 dapat diketahui bahwa wilayah Desa Lumban Binanga sebesar $(42,85 \%)$ atau seluas 45 $\mathrm{Ha}$ merupakan lahan persawahan. Lahan Persawahan inilah yang dipakai sebagai sumber matapencaharian oleh sebagian besar penduduk di Desa Lumban Binanga, sementara sebagian kecil $(0,47 \%)$ atau seluas $0,5 \mathrm{Ha}$ dipergunakan untuk lahan perkantoran.

Berdasarkan data yang diperoleh, jumlah penduduk Desa Lumban Binanga sebanyak 660 Jiwa dengan 93 KK yang tersebar di 3 Dusun. Jumlah Penduduk di 3 Dusun tersebut disajikan pada tabel 2.

Tabel 2. Jumlah Penduduk di Desa Lumban Binanga Tahun 2015

\begin{tabular}{|l|l|r|r|}
\hline No & \multicolumn{1}{|c|}{ Dusun } & $\begin{array}{c}\text { Jumlah Penduduk } \\
\text { (Jiwa) }\end{array}$ & Jumlah KK \\
\hline 1 & I & 171 & 24 \\
2 & II & 290 & 41 \\
3 & III & 199 & 28 \\
\hline & Jumlah & 660 & 93 \\
\hline
\end{tabular}

Sumber : Kantor Kepala Desa Lumban Binanga, 2016

Dari tabel 2 dapat diketahui bahwa penduduk yang paling banyak terdapat di Dusun II dengan jumlah penduduk 290 Jiwa dengan $41 \mathrm{KK}$ dan yang paling sedikit terdapat pada Dusun I yaitu sebanyak 171 Jiwa dengan 24 KK. Mengacu pada tabel 2, rata-rata jumlah anggota rumah tangga di Desa Lumban Binanga juga dapat diketahui dengan cara membagikan jumlah penduduk terhadap jumlah $\mathrm{KK}$, sehingga diperoleh rata-rata anggota rumah tangga di Desa Lumban Binanga adalah 7 jiwa. Hal ini menunjukkan bahwa program keluarga berencana dengan slogan dua anak lebih baik belum diterapkan oleh masyarakat.

\section{Identitas Responden}

a. Responden Berdasarkan Umur 
Umur responden merupakan salah satu karakteristik yang digunakan dalam pengkajian untuk mengetahui apakah responden tergolong usia produktif atau tidak. Untuk melihat responden berdasarkan kelompok umur dapat dilihat pada tabel 3 berikut.

Tabel 3. Distribusi Responden Berdasarkan Umur Di Desa Lumban Binanga Tahun 2017

\begin{tabular}{|c|c|r|r|}
\hline No. & Golongan Umur (tahun) & Frekuensi & Persentase (\%) \\
\hline 1 & $30-34$ & 4 & 13,33 \\
2 & $35-39$ & 7 & 23,33 \\
3 & $40-44$ & 9 & 30,00 \\
4 & $45-49$ & 2 & 6,66 \\
5 & $50-54$ & 2 & 6,66 \\
6 & $55-59$ & 1 & 3,33 \\
7 & $60-64$ & 1 & 3,33 \\
8 & $65-69$ & 2 & 6,66 \\
9 & $70-74$ & 2 & 6,66 \\
\hline & & 30 & 100 \\
\hline
\end{tabular}

Sumber : Data Primer (Olahan, 2017)

Berdasarkan tabel 3 dapat diketahui bahwa data kelompok umur responden yang paling banyak berada pada kelompok umur 40-44 tahun sebanyak 9 responden atau 30\% dan kelompok umur responden paling sedikit adalah umur 55-59 dan 60-64 tahun sebanyak 1 responden atau 3,33\%. Jika dilihat dari struktur penduduk berdasarkan usia produktif yang berkisar dari usia 15-64 tahun dan penduduk usia non produktif yaitu usia $<15$ tahun dan $>64$ tahun, maka seluruh responden yang ada di Desa Lumban Binanga yang berjumlah 30 responden masuk kedalam kategori usia produktif.

b. Responden Berdasarkan Agama dan Suku

Bangsa Indonesia merupakan negara yang beragam suku dan agama.
Dalam penelitian ini semua responden berjumlah $30 \mathrm{KK}$, dengan jumlah responden yang menganut agama Kristen Protestan $80 \%$ atau 24 responden, yang menganut agama Khatolik sebanyak $20 \%$ atau 6 responden. Sedangkan berdasarkan suku maka $30 \mathrm{KK}$ yang dijadikan sebagai responden adalah 100\% suku Batak Toba, kondisi ini sejalan dengan penduduk di Desa Lumban Binanga yang memang lebih banyak penduduknya beragama Kristen Protestan dengan suku paling banyak adalah suku Batak Toba yang bisa dilihat pada tabel 5 dan tabel 6 .

c. Responden Berdasarkan Lama Bekerja Sebagai Nelayan di Desa Lumban Binanga

Data tentang responden berdasarkan lama bekerja bisa dilihat pada tabel 4 berikut ini.

Tabel 4. Jumlah Responden Berdasarkan Lama Bekerja

\begin{tabular}{|c|c|c|c|}
\hline No & Lama Bekerja (Tahun) & Frekuensi & Persentase (\%) \\
\hline 1 & $1-9$ & 6 & 20,00 \\
2 & $10-19$ & 12 & 40,00 \\
3 & $20-29$ & 4 & 13,33 \\
4 & $30-39$ & 6 & 20,00 \\
5 & $40-49$ & 1 & 3,33 \\
6 & $50-59$ & 1 & 3,33 \\
\hline & Jumlah & 30 & 100 \\
\hline
\end{tabular}

Sumber : Data Primer (Olahan, 2017) 
Berdasarkan tabel 4 dapat dilihat bahwa lamanya bekerja responden yang paling banyak berada pada 10-19 tahun dengan jumlah 12 responden atau sekitar $40 \%$. Hal ini membuktikan bahwa pekerjaan sebagai nelayan memang sangat digeluti oleh masyarakat Desa Lumban Binanga, hal ini dapat diperkuat dengan adanya responden yang tetap bertahan hingga 50-59 tahun bekerja sebagai nelayan dengan jumlah 1 responden atau sekitar 3,33\%. Selain itu menurut hasil

Tabel 5. Jumlah Responden Berdasarkan

Anggota Keluarga Yang Ikut Bekerja

Sebagai Nelayan Di Desa Lumban Binanga Tahun 2017

\begin{tabular}{|c|c|r|r|}
\hline No & $\begin{array}{c}\text { Jumlah } \\
\text { Anggota }\end{array}$ & Frekuensi & $\begin{array}{r}\text { Persentase } \\
(\%)\end{array}$ \\
\hline 1 & 1 & 6 & 20,00 \\
2 & 2 & - & - \\
3 & Tidak Ada & 24 & 80,00 \\
\hline & Jumlah & 30 & 100 \\
\hline
\end{tabular}

Sumber : Data Primer (Olahan, 2017)

Berdasarkan tabel 5 dapat diketahui bahwasanya dari 30 responden terdapat 6 responden atau sekitar $20 \%$ yang anggota keluarga lainnya ikut bekerja sebagai nelayan, sedangkan sebanyak 24 responden atau sekitar $80 \%$ lebih memilih wawancara juga menunjukkan bahwasanya ada responden yang menggeluti pekerjaannya sudah lama sejak dari mereka belum berumah tangga.

d. Responden Berdasarkan Anggota Keluarga Yang Ikut Bekerja Sebagai Nelayan

Hasil penelitian tentang jumlah anggota keluarga yang ikut serta bekerja sebagai nelayan dapat dilihat pada tabel 5 berikut.

tidak ikut bekerja sebagai nelayan. Hal ini membuktikan bahwa pekerjaan sebagai nelayan lebih pantas dan hanya digeluti oleh kepala keluarga saja dan tidak diikuti oleh anggota keluarga lain.

e. Responden Berdasarkan Tingkat

Pendidikan Terakhir

Tingkat pendidikan pada suatu daerah merupakan hal yang sangat penting dan juga merupakan salah satu faktor yang mendukung kemajuan suatu daerah. Semakin baik atau semakin tinggi tingkat pendidikan suatu masyarakat atau suatu daerah maka semakin cepat daerah tersebut dapat berkembang. Karakteristik pendidikan responden berdasarkan tingkat pendidikan di daerah penelitian dapat dilihat pada tabel 6 berikut:

Tabel 6. Jumlah Responden Berdasarkan Tingkat Pendidikan Terakhir Di Desa Lumban Binanga Tahun 2017

\begin{tabular}{|c|c|c|c|}
\hline No & Tingkat Pendidikan & Frekuensi & Persentase (\%) \\
\hline 1 & SD & 6 & 20,00 \\
2 & SMP & 9 & 30,00 \\
3 & SMA & 15 & 50,00 \\
4 & PT & - & - \\
\hline & Jumlah & 30 & 100 \\
\hline
\end{tabular}

Sumber : Data Primer (Olahan, 2017)

Berdasarkan tabel 6 dapat diketahui bahwa tingkat pendidikan responden beranekaragam, dari tingkat SD sampai ada ke tingkat SMA. Pendidikan yang paling banyak ditempuh oleh responden adalah tingkat SMA yaitu sebanyak 15 responden atau 50\%, dan yang paling sedikit berada pada tingkat SD dengan jumlah 6 responden atau 20\%.
Dari tabel ini menunjukkan bahwa tingkat pendidikan yang masih tergolong rendah membuat para responden kesulitan dalam mencari pekerjaan sehingga pada akhirnya lebh memilih bekerja sebagai seorang nelayan yang tidak perlu membutuhkan keterampilan khusus.

f. Responden Berdasarkan Jumlah Tanggungan 
Jumlah tanggungan keluarga mempengaruhi kesejahteraan keluarga, dimana semakin besar jumlah tanggungan maka akan semakin besar tingkat pengeluaran. Jumlah tanggungan dalam penelitian ini adalah seluruh anak dan tanggungan hanya yang menjadi beban dalam keluarga. Jumlah tanggungan keluarga dalam penelitian ini dapat dilihat pada tabel 7 berikut ini.

Tabel 7. Jumlah Responden Berdasarkan BesarnyaTanggungan Keluarga Di Desa Lumban BinangaTahun 2017

\begin{tabular}{|c|c|c|c|}
\hline No & $\begin{array}{c}\text { Jumlah } \\
\text { Tanggungan } \\
\text { (Jiwa) }\end{array}$ & Frekuensi & $\begin{array}{c}\text { Persentase } \\
(\%)\end{array}$ \\
\hline 1 & $1-3$ & 11 & 36,66 \\
2 & $4-6$ & 15 & 50,00 \\
3 & $>6$ & 4 & 13,33 \\
\hline & Jumlah & 30 & 100 \\
\hline
\end{tabular}

Sumber : Data Primer (Olahan, 2017)
Berdasarkan tabel 7 dapat diketahui bahwa jumlah anak yang menjadi tanggungan kepala keluarga yang terbesar ada pada 4-6 jiwa, dengan frekuensi 15 responden atau sekitar 50\%. Dengan jumlah tanggungan keluarga yang besar akan sangat berpengaruh terhadap pendapatan dan kesejahteraan keluarga.

g. Responden Berdasarkan Tingkat
Pendapatan
Peningkatan ekonomi sangat dipengaruhi oleh pendapatan keluarga. Pendapatan adalah kemampuan suatu rumah tangga atau perorangan untuk memperoleh barang dan juga pendapatan yang diperoleh masyarakat terhadap berbagai macam kebutuhan. Dalam penelitian ini pendapatan yang dimaksud adalah hanya pendapatan kepala keluarga saja yang diperoleh dari hasil bekerja sebagai nelayan. Untuk lebih jelasnya dapat dilihat pada tabel 8 sebagai berikut:

Tabel 8. Distribusi Responden Berdasarkan Pendapatan Kepala Keluarga di Desa Lumban Binanga Tahun 2017

\begin{tabular}{|c|c|c|c|}
\hline No & Pendapatan/Bulan & Frekuensi & Persentase (\%) \\
\hline 1 & $<$ Rp 1.250.000 & 4 & 13,33 \\
2 & Rp 1.250.000 - Rp 1.750.000 & 19 & 63,33 \\
3 & >Rp 1.750.000 & 7 & 23,33 \\
\hline & Jumlah & 30 & 100 \\
\hline
\end{tabular}

Sumber : Data Primer (Olahan, 2017)

Berdasarkan tabel 8 frekuensi responden menurut besarnya pendapatan kepala keluarga di Desa Lumban Binanga berada pada tingkat Rp 1.250.000 - Rp 1.750.000 dengan jumlah 19 responden atau sekitar 63,33\%. Hal ini bila dikaitkan dengan Pendapatan Minimun Kabupaten Toba Samosir (UMK) tahun 2016 yaitu Rp 1.735.000, maka pendapatan masyarakat di Desa Lumban Binanga masih berada di bawah standar yang sudah ditentukan.Rendahnya pendapatan kepala keluarga inilah yang akan mendorong mereka ataupun anggota keluarga lain untuk melakukan berbagai strategi untuk tetap bertahan hidup.

\section{Strategi Bertahan Hidup yang dilakukan responden keluarga Nelayan}

\section{Diversifikasi Kerja}

Diversifikasi Kerja adalah Strategi adaptasi yang digunakan oleh nelayan untuk menghadapi ketidakpastian penghasilan yaitu dengan mengkombinasikan pekerjaan. Kegiatan penangkapan ikan selalu di kombinasikan dengan pekerjaan lain atau pekerjaan sampingan dan dilakukan secara bergantian. Demikian juga masyarakat nelayan yang ada di Desa Lumban Binanga melakukan diversifikasi dengan tujuan untuk memperoleh penghasilan tambahan, sehingga mampu untuk memcukupi kebutuhan rumah tangga. Dari hasil penelitian dapat diketahui bahwa sebanyak 28 responden atau sekitar 93,33\% yang memilih untuk melakukan diversifikai kerja 
atau memiliki pekerjaan sampingan, sedangkan 2 responden lainnya atau $6,66 \%$ memilih tidak melakukan diversifikasi kerja. Hal ini dapat membuktikan bahwa penghasilan yang didapat dari pekerjaan utama sebagai nelayan belum dirasa cukup untuk memenuhi seluruh kebutuhan rumah tangga mereka. Oleh karena itu, keluarga nelayan memilih diversifikasi kerja sebagai salah satu strategi untuk tetap bertahan hidup.

Diversifikasi kerja yang dilakukan oleh keluarga nelayan juga bervariasi, ada yang memilih untuk bertani, ada yang memilih untuk menarik becak, memelihara hewan dan lain sebagainya. Untuk lebih jelasnya mengenai jenis diversifikasi kerja yang dipilih keluarga nelayan dapat dilihat pada tabel 9 berikut ini:

Tabel 9. Jenis Diversifikasi Kerja Keluarga Nelayan di Desa Lumban Binanga Tahun 2017

\begin{tabular}{|c|l|c|c|}
\hline No & Jenis Diversifikasi Kerja & Frekuensi & Persentase (\%) \\
\hline 1 & Bertani & 16 & 57,14 \\
2 & Memelihara Hewan & 7 & 25,00 \\
3 & Tukang Becak & 2 & 7,14 \\
4 & Bertukang & 1 & 3,57 \\
5 & Buruh Tani & 2 & 7,14 \\
\hline & Jumlah & 28 & 100 \\
\hline
\end{tabular}

Sumber : Data Primer (Olahan, 2017)

Berdasarkan tabel 9 dapat dilihat bahwa terdapat sebanyak 16 responden atau sekitar $57,14 \%$ yang memilih untuk bertani sebagai pekerjaan sampingan, dan hanya sebanyak 1 responden atau sekitar 3,57\% yang memilih bertukang untuk pekerjaan sampingan. Hal ini disebabkan karena lahan yang terdapat di Desa Lumban Binanga adalah tanah subur yang baik dimanfaatkan sebagai lahan pertanian. Selain itu menurut hasil wawancara, responden memilih untuk bertani karena jam kerja yang tidak terlalu lama, sehingga tidak mengganggu pekerjaan utamanya sebagai nelayan.

Pendapatan yang diperoleh dari pekerjaan sampingan juga bervariasi sesuai dengan pekerjaan sampingan yang dimiliki. Untuk melihat lebih jelasnya mengenai pendapatan yang diperoleh dari pekerjaan sampingan dapat dilihat dari tabel 10 berikut:

Tabel 10. Jumlah Responden Berdasarkan PendapatanYang Diperoleh Dari Pekerjaan Sampingan Di Desa Lumban Binanga Tahun 2017

\begin{tabular}{|c|c|c|c|}
\hline No & Pendapatan & Frekuensi & Persentase (\%) \\
\hline 1 & $<\operatorname{Rp~750.000}$ & 4 & 14,28 \\
2 & Rp 750.000 - Rp 1.000.000 & 6 & 21,42 \\
3 & $>$ Rp 1.000.000-Rp 1.250.000 & 16 & 57,14 \\
4 & $>$ Rp 1.250.000 & 2 & 7,14 \\
\hline & Jumlah & 28 & 100 \\
\hline
\end{tabular}

Sumber : Data Primer (Olahan, 2017)

Berdasarkan tabel 10 dapat diketahui bahwa terdapat 16 responden atau sekitar $57,14 \%$ yang memiliki penghasilan diantara Rp 1.000.000 - Rp 1.250.000 dari pekerjaan sampingan yang mereka geluti. Ini berarti bahwa dengan adanya penghasilan yang diperoleh dari pekerjaan sampingan tersebut, dapat membantu meringankan beban rumah tangga mereka.

\section{Memanfaatkan Anggota Keluarga Lain}

Banyaknya kebutuhan akan hidup menuntut anggota keluarga lainnya untuk 
ikut serta dalam bekerja, karena pada kenyataannya penghasilan yang diperoleh kepala keluarga dari pekerjaan utama sebagai nelayan dan penghasilan yang diperoleh dari pekerjaan sampingan belum cukup untuk memenuhi seluruh biaya kehidupan rumah tangga mereka. Oleh karena itu, maka keluarga nelayan dalam penelitian ini memilih strategi lainnya untuk bisa bertahan hidup, yaitu dengan mengikutsertakan anggota keluarga lainnya dalam bekerja

Berdasarkanhasil penelitian dapat diketahui bahwa terdapat sebanyak 26 responden atau sekitar $86,66 \%$ yang mengikutsertakan istrinya untuk bekerja,

Tabel 11. Jumlah Responden Berdasarkan Jenis Pekerjaan Istri Nelayan di Desa Lumban Binanga Tahun 2017.

\begin{tabular}{|c|l|c|c|}
\hline No & $\begin{array}{c}\text { Jenis } \\
\text { Pekerjaan }\end{array}$ & Frekuensi & $\begin{array}{c}\text { Persentase } \\
(\%)\end{array}$ \\
\hline 1 & Bertani & 17 & 65,38 \\
2 & Buruh Tani & 5 & 19,23 \\
3 & Membuka & 4 & 15,38 \\
& Warung & 26 & 100 \\
\hline & Jumlah & 26 &
\end{tabular}

Sumber : Data Primer (Olahan, 2017)

Berdasarkan tabel 11 dapat dilihat bahwa terdapat sebanyak 17 responden atau sekitar $65,38 \%$ yang istrinya memilih untuk bekerja sebagai bertani, dan hanya sebanyak 4 responden atau sekitar 15,38\% yang memilih untuk membuka warung di depan rumah. Hal ini dikarenakan oleh para suami atau kepala keluarga yang juga memilih untuk bertani sebagai pekerjaan sampingannya, sehingga istri ikut membantu suami untuk bekerja sebagai petani.

Penghasilan yang diperoleh istri dari bekerja sebagai petani, telah digabungkan dengan pendapatan responden dari pekerjaan sampingannya sebagai petani. Hal ini dikarenakan suami dan istri bekerja bersama di lahan sawah yang sama, sehingga penghasilan yang didapat telah digabungkan. Akan tetapi, istri yang memilih pekerjaan lain diluar dari bertani, yaitu buruh tani dan membuka warung memiliki penghasilan yang tidak dan hanya 4 responden atau sekitar $13,33 \%$ yang tidak membiarkan istrinya untuk bekerja. Ini berarti bahwa pendapatan yang diperoleh oleh kepala keluarga dari pekerjaan utama dan sampingan belum cukup untuk memenuhi kebutuhan rumah tangga mereka.

Pekerjaan yang digeluti oleh istri nelayan sebagai salah satu bentuk strategi bertahan hidup juga beranekaragam. Ada yang memilih untuk bertani, buruh tani dan ada juga yang memilih untuk membuka warung kecil-kecilan di depan rumah. Untuk lebih jelasnya dapat dilihat pada tabel 11 berikut:

menentu, yaitu berada dikisaran antara $\mathrm{Rp}$ 500.000 - Rp 750.000 per bulannya. Dalam hal ini, dapat diketahui bahwa sekitar $86 \%$ istri dari responden telah membantu meringankan beban kepala keluarga dan memberikan kontribusinya dalam memenuhi kebutuhan rumah tangga mereka.

Selain istri, anak merupakan anggota keluarga lainnya yang bisa dimanfaatkan untuk bekerja sebagai slah satu bentuk dari strategi bertahan hidup. Dapat hasil wawancara dapat diketahui bahwa, hanya 3 responden atau sekitar $10 \%$ yang memilih untuk mengikutsertakan anak dalam bekerja sebagai salah satu brntuk strategi bertahan hidup. Sedangkan terdapat 27 responden atau sekitar 90\% yang memilih untuk tidak mengikutsertakan anak dalam bekerja. Hal ini disebabkan karena anak responden yang masih berada pada usia sekolah, sehingga tidak memiliki waktu yang cukup untuk ikut membantu orangtua dalam bekerja. Sehingga dapat disimpulkan bahwa memanfaatkan anggota keluarga lainnya untuk bekerja sebagai salah satu bentuk strategi bertahan hidup, anak dapat dikatakan tidak memberikan kontribusi atau peran.

\section{Menekan Pengeluaran/Berhemat}

Pendapatan yang kecil dengan biaya kebutuhan yang besar, mendorong kepala keluarga untuk melakukan strategi bertahan hidup lainnya, yaitu dengan 
meminimalisir pengeluaran atau berhemat. Menekan pengeluaran yang dilakukan oleh keluarga nelayan dalam penelitian ini juga bermacam jenis, dimulai dari menekan pengeluaran untuk biaya pangan, biaya kesehatan dan biaya pendidikan.

Dari hasil wawancara dapat diketahui bahwa keseluruhan responden atau 30 responden memilih untuk berhemat sebagai bentuk dari strategi bertahan hidup, sehingga dapat disimpulkan bahwa keseluruhan respon telah berusaha untuk menyeimbangkan antara penghasilan yang didapat dengan pengeluaran untuk biaya kebutuhan rumah tangga mereka. Berikut ini akan dijelaskan mengenai jenis-jenis berhemat yang dilakukan oleh keluarga nelayan di Desa Lumban Binanga, untuk yang pertama adalah menekan biaya pangan.

Dari hasil wawancara dapat diketahui bahwa keseluruhan responden memilih untuk menekan pengeluaran atau berhemat pada biaya pangan sebagai bentuk strategi bertahan hidup keluarga nelayan. Akan tetapi menekan biaya pangan yang dimaksud dalam hal ini bukanlah mengurangi kuantitas atau frekuensi makan setiap harinya, akan tetapi yang dimaksud adalah mengurangi kualitas makanan yang dikonsumsi setiap harinya. Dengan demikian anggota keluarga nelayan tetap bisa makan sebanyak 3 kali dalam sehari dengan kualitas yang makanan yang sederhana.

Selain melakukan penghematan terhadap biaya pangan, strategi lain adalah melakukan penghematan terhadap biaya kesehatan dan pendidikan anak. Berdasarkan hasil penelitian, keseluruhan responden memilih untuk melakukan penghematan terhadap biaya kesehatan. Dalam hal ini yang dimaksud dengan menghemat biaya kesehatan adalah ketika ada anggota keluarga yang sakit, maka akan dibawa berobat ke bidan desa atau puskesmas, karena biaya berobat di puskesmas dan bidan desa yang terjangkau. Sedangkan untuk biaya pendidikan, keseluruhan responden memilih untuk tidak melakukannya. Berapapun biaya yang dibutuhkan untuk biaya pendidikan anak, maka mereka akan menyanggupinya. Hal ini dapat disimpulkan bahwa pola pikir responden yang semakin maju dan beranggapan bahwa pendidikan sangat dibutuhkan pada saat ini demi masa depan yang baik untuk anak mereka.

\section{Strategi Jaringan Sosial}

Strategi jaringan adalah strategi yang dilakukan dengan cara memanfaatkan jaringan sosial. Strategi jaringan merupakan strategi bertahan hidup yang dilakukan dengan cara menjalin relasi, baik formal maupun dengan lingkungan sosialnya dan lingkungan kelembagaan (misalnya meminjam uang kepada tetangga, mengutang di warung atau toko, memanfaatkan program kemiskinan, meminjam uang ke rentenir atau bank dan sebagainya. Demikian juga keluarga nelayan yang ada di Desa Lumban Binanga, memanfaatkan jaringan sosial atau organisasi yang diikuti di desa tersebut sebagai salah satu strategi untuk bertahan hidup.

Berdasarkan hasil wawancara dapat diketahui bahwa terdapat sebanyak 27 responden atau sekitar $90 \%$ yang mengikuti organisasi di desa Lumban Binanga. Ini berarti bahwa masyarakat yang berada di desa Lumban Binanga selain sibuk untuk bekerja, masih memberikan waktunya untuk mengikuti kegiatan organisasi atau perkumpulan sosial, sehingga rasa toleransi dan kekeluargaan masih dijunjung tinggi di Desa Lumban Binanga.

Organisasi yang ada di Desa Lumban Binanga juga beragam jenisnya, masyarakat di Desa Lumban Binanga memilih organisasi sesuai dengan minat mereka. Organisasi tersebut antara lain adalah kelompok nelayan, kelompok tani, partangiangan (perkumpulan agama) dan lain sebagainya. Untuk lebih jelasnya lagi dapat dilihat pada tabel 12 berikut ini: 
Tabel 12. Jenis Organisasi Yang Diikuti Keluarga Nelayan Di Desa Lumban Binanga Tahun 2017

\begin{tabular}{|c|l|c|c|}
\hline No & \multicolumn{1}{|c|}{ Jenis Organisasi } & Frekuensi & Persentase (\%) \\
\hline 1 & Kelompok Nelayan & 16 & 59,25 \\
2 & Kelompok Tani & 9 & 33,33 \\
3 & Organisasi Keagamaan & 2 & 7,40 \\
\hline & Jumlah & 27 & 100 \\
\hline
\end{tabular}

Sumber : Data Primer (Olahan, 2017)

Berdasarkan tabel 12 dapat dilihat bahwa terdapat sebanyak 16 responden atau sekitar $59,25 \%$ yang mengikuti organisasi pada kelompok nelayan, sedangkan hanya terdapat 2 responden atau sekitar $7,40 \%$ yang mengikuti organisasi keagamaan. Hal ini dapat dilihat bahwa responden banyak memilih organisasi perkumpulan nelayan karena kebutuhan, dalam arti organisasi yang diikuti disesuaikan dengan pekerjaan mereka sebagai nelayan.

Berdasarkan hasil wawancara, organisasi atau perkumpulan yang diikuti oleh keluarga nelayan di Desa Lumban Binanga, banyak membantu anggota dalam pekerjaannya. Pemerintah akan memberikan bantuan kepada organisasi sesuai dengan kebutuhan para anggotanya. Seperti alat-alat menangkap ikan yang diperuntukkan kepada nelayan yang mengikuti perkumpulan nelayan, alat-alat pertanian bagi anggota yang mengikuti perkumpulan tani, dan lain sebagainya. Hal ini tentu sangat membantu masyarakat mempermudah pekerjaan mereka.

Selain organisasi, jaringan sosial lain yang dimanfaatkan oleh keluarga nelayan sebagai bentuk dari strategi bertahan hidup adalah seperti meminjam kepada tetangga, tauke atau bahkan kepada bank. Untuk lebih jelasnya dapat dilihat pada tabel 13 berikut ini:
Tabel 13. Jaringan Sosial Yang Dimanfaatkan Oleh Keluarga Nelayan Di Desa Lumban Binanga Tahun 2017.

\begin{tabular}{|l|l|c|c|}
\hline No & $\begin{array}{c}\text { Jaringan } \\
\text { Sosial }\end{array}$ & Frekuensi & $\begin{array}{c}\text { Persentase } \\
(\%)\end{array}$ \\
\hline 1 & Tetangga & 7 & 23,33 \\
2 & Saudara & 3 & 10,00 \\
3 & Tauke & 16 & 53,33 \\
4 & Koperasi & - & - \\
5 & Bank & 4 & 13,33 \\
\hline & Jumlah & 30 & 100 \\
\hline
\end{tabular}

Sumber : Data Primer (Olahan, 2017)

Berdasarkan tabel 13 dapat diketahui bahwa terdapat 16 responden atau sekitar $53,33 \%$ yang memilih untuk meminjam kepada tauke ketika berada dalam keadaan yang mendesak atau kesulitan. Meminjam kepada tauke merupakan pilihan terakhir yang terpaksa dilakukan oleh keluarga nelayan, dan hanya ketika keadaan benar-benar mendesak.

Dengan menganalisis data dari lapangan bahwa responden tidak hanya melakukan satu strategi dalam pemenuhan kebutuhan atau dalam bertahan hidup, namun ada responden yang yang melakukan strategi campuran, baik itu strategi ekonomi yaitu diversifikasi kerja, memanfaatkan anggota keluarga lainnya, menekan pengeluaran, maupun strategi sosial dengan memanfaatkan jaringan sosial. Untuk lebih jelasnya dapat dilihat pada tabel 14 berikut ini:

Tabel 14. Jumlah Responden Yang Melakukan Strategi Campuran

\begin{tabular}{|l|l|r|r|}
\hline No & \multicolumn{1}{|c|}{ Strategi Campuran } & Frekuensi & Persentase (\%) \\
\hline 1 & MAKL + MP + JS & 28 & 93,33 \\
2 & DK + MP + JS & 26 & 86,66 \\
3 & DK + MAKL + MP + JS & 26 & 86,66 \\
\hline
\end{tabular}

Sumber: Data Primer (Olahan, 2017) 
Ket:

DK = Diversifikasi Kerja

MP = Menekan Pengeluaran

MAKL = Memanfaatkan Anggota

Keluarga Lain

JS = Jaringan Sosial

Dari tabel 14 dapat diketahui bahwa terdapat sebanyak 26 responden atau sekitar $86,66 \%$ responden yang melakukan strategi campuran tersebut. Sedangkan terdapat 4 responden atau sekitar 13,33\% memilih tidak melakukan strategi campuran. Artinya bahwa keempat strategi tersebut seluruhnya dimanfaatkan oleh responden dalam bertahan hidup. Hal ini dapat disebabkan karena satu strategi saja tidak mampu bagi keluarga nelayan untuk tetap bertahan hidup.

Melalui berbagai strategi yang digunakan oleh keluarga nelayan, dapat diharapkan bahwa pendapatan akan ikut meningkat sehingga mampu memnuhi seluruh kebutuhan rumah tangga mereka. Pada tabel 15 berikut ini dapat dilihat pendapatan keluarga nelayan secara keseluruhan:

Tabel 15. Jumlah Responden Berdasarkan Pendapatan Secara Keseluruhan

\begin{tabular}{|c|c|c|c|}
\hline No & Total Pendapatan & Frekuensi & Persentase (\%) \\
\hline 1 & Rp 1.500.00-Rp 2.000.000 & 2 & 6,67 \\
2 & >Rp 2.000.000-Rp 3.000.000 & 22 & 73,33 \\
3 & >Rp 3.000.000-Rp 4.000.000 & 6 & 20 \\
\hline & Jumlah & 30 & 100 \\
\hline
\end{tabular}

Sumber : Data Primer (Olahan, 2017)

Berdasarkan tabel 15 dapat diketahui bahwa pendapatan keseluruhan keluarga nelayan berada dikisaran $\mathrm{Rp}$ 2.000.000-Rp 3.000.000 dengan frekuensi 22 responden, dengan demikian bahwa setelah melakukan strategi maka pendapatan keluarga nelayan semakin meningkat, dari semula masih berada dibawah UMK dan sekarang sudah berada di atas UMK.

\section{KESIMPULAN DAN SARAN Kesimpulan}

Berdasarkan hasil pembahasan yang telah diuraikan maka diperoleh kesimpulan bahwa pekerjaan sebagai nelayan Danau Toba tidak mampu mensejahterakan seluruh anggota keluarga, karena dengan penghasilan Rp. 1.288.000-Rp. 1.930.000 perbulannya tidak cukup untuk memenuhi seluruh kebutuhan rumah tangga mereka. Oleh karena itu keluarga nelayan Danau Toba di Desa Lumban Binanga melakukan berbagai cara sebagai bentuk strategi bertahan hidup.

a) Untuk strategi ekonomi Keluarga Nelayan memilih (1) diversifikasi kerja atau kepala keluarga memiliki pekerjaan sampingan sebanyak 28 responden atau 93,33\%, (2)Terdapat 26 responden atau $86,66 \%$ yang mengikutsertakan istri untuk bekerja dengan jenis pekerjaan dominan yaitu sebanyak 17 responden atau 65,38\% yang memilih untuk bekerja sebagai petani, (3) Sebanyak 30 responden atau $100 \%$ memilih untuk melakukan penghematan atau menekan pengeluaran

b) Untuk strategi sosial, sebanyak 30 responden atau $100 \%$ memilih untuk memanfaatkan jaringan sosial sebagai strategi bertahan hidup yang selanjutnya, dimana sebanyak 16 responden atau 53,33\% memilih untuk meminjam uang kepada tauke padi.

c) Untuk strategi campuran, terdapat 26 responden atau $86,66 \%$ yang memilih untuk melakukannya, yaitu dengan cara melaksanakan keempat strategi tersebut secara bersamaan.

\section{Saran}

Berdasarkan hasil penelitian yang telah dilakukan, maka dapat dikemukakan saran-saran sebagai berikut: 
1. Dalam upaya peningkatan kesejahteraan anggota keluarga nelayan, dibutuhkan usaha dan dukungan yang maksimal dari pemerintah baik dari segi pemodalan alat dan peralatan tangkap nelayan dimana selama ini nelayan di Desa Lumban Binanga masih menggunakan alat-alat yang sederhana sehingga dengan adanya alat maupun peralatan yang lebih modern maka akan membantu para nelayan dalam meningkatkan hasil tangkapan ikan.

2. Selain itu pemerintah juga perlu menyediakan modal bergulir seperti Kredit Usaha Rakyat (KUR) sehingga keluarga nelayan mampu membuka usaha baru yang memiliki peluang besar dalam meningkatkan kesejahteraan mereka, ataupun memberikan bantuan yang didapatkan secara langsung dan diharapkan bantuan tersebut tepat pada sasaran.

3. Pemerintah juga perlu menyediakan bibit bibit ikan yang beragam dan dilepaskan di Danau Toba, sehingga dengan demikian hasil tangkapan nelayan bisa meningkat dengan jenis ikan yang beragam.

4. Bagi para keluarga nelayan diharapkan agar tetap menjaga kelestarian Danau Toba dengan cara tidak mencemarinya, dan tidak menangkap ikan secara sembarangan, atau tidak menangkap ikan yang masih kecil sehingga ikan-ikan yang ada di danau tetap ada untuk kemudian hari.

\section{DAFTAR PUSTAKA}

Arkatut, Robi. 2013. Strategi Istri Nelayan dalam Menunjang Penghasilan Keluarga di Dusun Merpati Desa Sungai Kakap Kecamatan Sungai Kakap Kabupaten Kubu Raya. Sociodev, Jurnal S1 IImu Sosiatri, (Online), Vol 2, No 2.

Asdi. Yuda. 2016. Analisis Keberadaan Pabrik Tepung Tapioka CV Sentral Intan Terhadap Kondisi Sosial Ekonomi Masyarkat Desa Ratna Daya

$$
\text { Kecamatan Raman Utama }
$$

Kabupaten Lampung Timur. Skripsi. Lampung: Fakultas Ekonomi dan Bisnis Universitas Malang.

Bungin, Burhan. 2001. Metodologi Penelitian Kualitatif. Jakarta: PT Raja Grafindo Persada.

Christanto, Joko. 2010. Strategi Penghidupan Nelayan Dalam Peningkatan Ekonomi Masyarakat Di Kecamatan Sasak Ranah Pasisie Dan Sungai Beremas. Jurnal Dinamika Ekonomi Pembangunan, (Online), Vol I, No 5.

Fitria, F., \& Pinem, M. (2012). Keadaan Sosial Ekonomi Masyarakat Nelayan Di Desa Beringin Kecamatan Beringin Kabupaten Deli Serdang. JURNAL GEOGRAFI, 4(2), 29-36.

Gianawati, Dyah. 2011. Strategi Dan Makna Bertahan Hidup Perempuan Pedesaan Etnis Madura Dan Jawa. Jurnal Dinamika Ekonomi Pembangunan, (Online), Vol I, No 5.

Karlita, Nanda. 2015. Strategi Bertahan Hidup Perempuan Di Daerah Pesisir Dusun Muara, Desa Muara, Kabupaten Tangerang, Banten. Skripsi. Bogor: Fakultas Ekplogi Manusia IPB.

Kristianti. 2014. Strategi Bertahan Hidup Nelayan Buruh Di Desa Meskom Kecamatan Bengkalis Kabupaten Bengkalis Provinsi Riau. Jurnal Berkala Perikanan Terubuk (Online), Vol 42, No 1.

Marbun, Leonardo dan Krishnayanti, Ika. 2002. Masyarakat Pinggiran Yang Kian Terlupakan. Jakarta: Era Grafia.

Nugroho, Iwan. 2004. Pembangunan Wilayah Perspektif Ekonomi, Sosial, dan Lingkungan. Jakarta: LP3S.

Purba, Irena. 2016. Strategi Bertahan Hidup Rumah Tangga Korban Erupsi Sinabung Pasca Relokasi Di Siosar Kecamatan Merek Kabupaten Karo. 
Skripsi. Medan: Jurusan Pendidikan Geografi FIS Unimed.

Rahmad, R., Panjaitan, B. R., Silaban, D., \& Muladi, M. R. (2017). The Impact of Rob Flood and Community Adaptation in Coastal Area of Medan Belawan, Medan City, North Sumatra, Indonesia. JURNAL GEOGRAFI, 9(2), 117-124.

Rosni, R. (2009). Penurunan Kualitas Ekosistem Mangrove Hubungannya dengan Pendapatan Masyarakat Nelayan Di Kecamatan Secanggang Kabupaten Langkat Provinsi Sumatera Utara. JURNAL GEOGRAFI, 1(1), 1326.

Sjafari, Agus. 2006. Kemiskinan dan Pemberdayaan Kelompok. Yogyakarta: Graha Ilmu.

Sudiyono. 2015. Strategi Bertahan Hidup Nelayan P. Rimau Balak Di Kabupaten Lampung Selatan. Jurnal Bina Praja, (Online), Vol 7, No 3, diakses pada 30 Maret 2017.
Sutan, Marah. 2014. Strategi Bertahan Hidup Masyarakat Penambang Pasir di Desa Pagaran Sibulussalam Kecamatan Panyabungan Kabupaten Mandailing Natal Ditinjau Dari Keadaan Sosial Ekonomi. Skripsi. Medan: Jurusan Pendidikan Geografi FIS Unimed.

Widodo, Slamet. 2014. Strategi Nafkah Berkelanjutan bagi RumahTangga Miskin di Daerah Pesisir.Makara, SosialHumaniora, (Online), Vol 15, No 1.

Wisdaningtyas, Karunia. 2011. Strategi Bertahan Hidup Masyarakat Nelayan Di Daerah Pencemaran Pesisir Studi Kasus Nelayan Kampung Bambu, Kelurahan Kali Baru, Kecamatan Cilincing, Jakarta Utara. Skripsi. Bogor: Fakultas Ekologi Manusia IPB.

Zebua, Y., Wildani, P. K., Lasefa, A., \& Rahmad, R. (2016). Faktor Penyebab Rendahnya Tingkat Kesejahteraan Nelayan Pesisir Pantai Sri Mersing Desa Kuala Lama Kabupaten Serdang Bedagai Sumatera Utara. JURNAL GEOGRAFI, 9(1), 88-98. 